\title{
Potassium depletion in heart failure and its relation to long-term treatment with diuretics: a review of the literature
}

\author{
D. B. MORGAN \\ M.D., M.R.C.Path.
}

\author{
L. BURKINSHAW \\ M.A., Ph.D.
}

\author{
C. DAVIDSON \\ M.A., M.B., M.R.C.P. \\ Departments of Chemical Pathology, Medical Physics and Medicine, \\ The General Infirmary, Leeds, England
}

\begin{abstract}
Summary
There have been many studies which suggest that patients with heart failure were potassium depleted. This depletion has been attributed to the use of potent diuretics, and these are now given with either potassium supplements or potassium-retaining diuretics. A detailed examination of the studies suggests that the reported decrease in body potassium compared with the results in healthy persons is not due to the diuretics. It can be partly explained by a failure to match patients and controls in terms of age, and the remaining difference can be explained by muscle wasting. There is therefore no evidence of a potassium depletion in these patients with heart failure.
\end{abstract}

\section{Introduction}

There are many studies which demonstrate that patients with heart failure have $20-30 \%$ less exchangeable potassium than healthy persons. This apparent deficit has usually been attributed to diuretics, which can certainly increase potassium excretion in the short term and cause sustained hypokalaemia. However, in a recent study the authors found that although some of a group of patients with heart failure treated with diuretics had hypokalaemia, total body potassium was on average only $5 \%$ less than in a group of healthy persons (Davidson et al., 1976). One possible explanation for the previously reported large apparent deficits is that there were large differences in age and body size between the patients and the controls in those studies and that these differences were not taken fully into account in the interpretation of the results. In order to examine this possibility the authors collected and compared published data on exchangeable potassium

Correspondence: Dr D. B. Morgan, Department of Chemical Pathology, The General Infirmary, Leeds, England.
$\left(\mathrm{K}_{\mathrm{e}}\right)$ in healthy persons and in patients with heart failure.

\section{Material}

As a first step the details were collected of the pub lished comparisons of exchangeable potassiumoind patients with heart failure and in healthy persinso (Aikawa, Harrell and Eisenberg, 1952; Blainey et 1954; Moore et al., 1954; Wilson et al., 1954웅 Birkenfeld et al., 1958; Deuxchaisnes et al., 1961 Flear et al., 1966; Singh, Hurley and North, 1969웡 White et al., 1969; Cox et al., 1971; Croxson, Neutze and John, 1972). For the subsequent, more detailed analyses, the authors collated all the published values] they could find for exchangeable potassium in healthy persons and patients with heart failure where the individual's sex, age and weight were. available as well as the exchangeable potassium? Height was noted if it had been measured, and for each patient with heart failure it was noted whethes the patient was oedematous and if he was taking diuretics alone or with potassium supplements Details were collected of 345 healthy controls (Corsa et al., 1950; Aikawa et al., 1952; Deane and Smith? 1952; Arons, Vanderlinde and Solomon, 1954 Blainey et al., 1954; Moore et al., 1954; Wilson et al. 1954; Ikkos et al., 1955; Sagild, 1956; Ljunggren N Ikkos and Luft, 1957; Birkenfeld et al., 1958 Crookes, Bluhm and Muldowney, 1959; MacGillivNㅗ ray, Buchanan and Billewicz, 1960; Talso et al. . $^{\omega}$ 1960; Deuxchaisnes et al., 1961; Singh et al., 1969; Cox et al., 1971; Skrabal, Arnot and Joplin, 1973) and 333 patients with heart disease (Aikawa et al. 1952; Blainey et al., 1954; Moore et al., 1954; Wilson et al., 1954; Aikawa and Fitz, 1956; Birken-ō feld et al., 1958; Deuxchaisnes et al., 1961; Olesen, 1964; Carroll, Gotterer and Altshuler, 1965; Flear $e \frac{\rho_{0}}{0}$ 
al., 1966; Olesen, 1968; Singh et al., 1969; White et al., 1969; Cox et al., 1971; Croxson et al., 1972; Davidson and Gillebrand, 1974; Olesen and Valentine, 1973).

\section{Results}

In eight studies between 1954 and 1975 the authors reported the values of exchangeable potassium $\left(\mathrm{K}_{\mathbf{e}}\right)$ in patients with heart failure and healthy persons (Blainey et al., 1954; Moore et al., 1954; Wilson et al., 1954; Aikawa and Fitz, 1956; Birkenfeld et al., 1958; Deuxchaisnes et al., 1961; Singh et al., 1969; Cox et al., 1971). The apparent $\mathrm{K}_{\mathrm{e}}$ deficit in each of these studies has been calculated as a percentage of the value in the healthy persons of the same sex in the same study. Fig. 1 shows the average apparent deficit in these series for men and women combined according to year; the apparent deficit was remarkably constant. Fig. 2 shows the percentage deficit according to sex, the presence or absence of oedema and whether the patients were taking a mercurial (MD) or non-mercurial (NMD) diuretic. This simple analysis, together with Fig. 1 suggests that the deficit of potassium in heart failure was about $20 \%$, that it has been about the same over the last 20 years, was greater in men than women, was if anything less with non-mercurial diuretics than with mercurial diuretics, was the same in oedematous as in nonoedematous patients, and was the same whether or not there was hypokalaemia. A detailed analysis is not possible, but there are observations which suggest that the apparent deficit is present even in

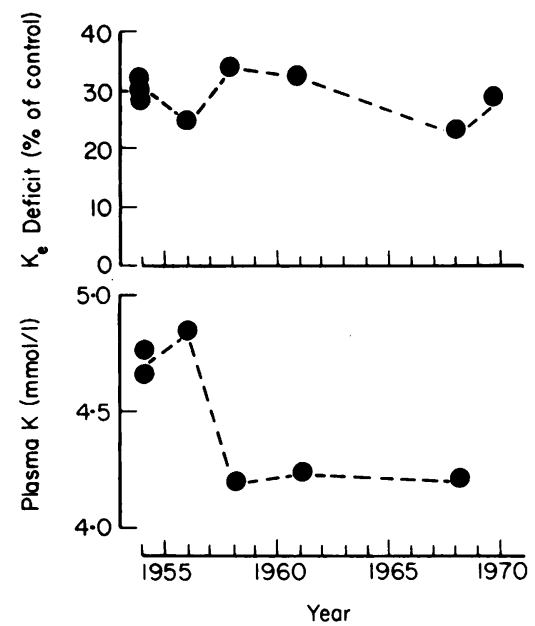

Fig. 1. The apparent deficit of total exchangeable potas$\operatorname{sium}\left(\mathrm{Ke}_{\mathrm{e}}\right)$ in patients with heart failure in eight published series. The deficit was calculated as the percentage difference from the values in healthy subjects included in the same study. The mean plasma potassium in the patients in the series is also shown.

patients taking potassium supplements (White et al., 1969).

The groups have been enlarged by including results of healthy subjects and patients from studies which did not involve comparison between patients with heart failure and controls.

There were of course many variables within the

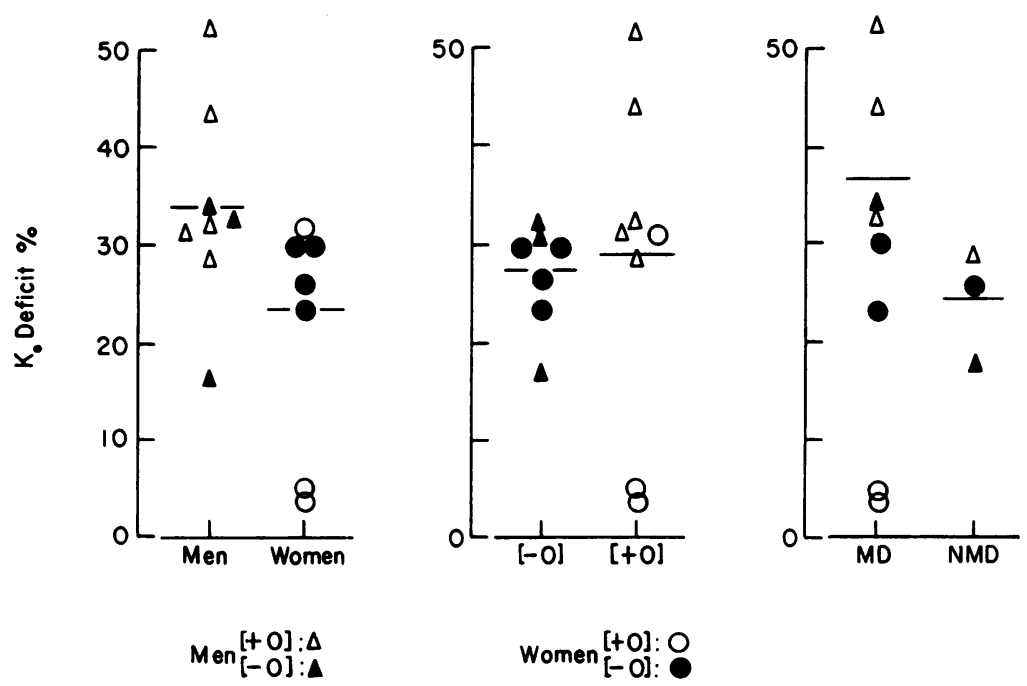

FIG. 2. The apparent deficit of total exchangeable potassium $\left(\mathrm{K}_{\mathrm{e}}\right)$ in patients with heart failure, according to sex, the presence or absence of oedema $(+0,-0)$ and whether the patients were taking a mercurial (MD) or non-mercurial diuretic (NMD). 
heart failure group but, in particular, concern was with the relation between the $\mathrm{K}_{\mathrm{e}}$ and diuretic treatment (D) and oedema (O). The results are presented in the form of the simple comparisons $(+D,-D)$ and $(+\mathrm{O},-\mathrm{O})$, but any difference has been confirmed in a more detailed analysis. For example, if there was a difference between the oedematous $(+O)$ and non-oedematous $(-\mathrm{O})$ groups then the four groups $(+\mathrm{O}+\mathrm{D},+\mathrm{O}-\mathrm{D},-\mathrm{O}+\mathrm{D},-\mathrm{O}-\mathrm{D})$ have been examined to make sure that the difference was present whether or not diuretics were given. The detailed results for these four groups are not given unless they contribute to the discussion.

Table 1 shows for men and women separately, the $\mathrm{K}_{\mathrm{e}}$ (mmol) in the controls and in the patients with heart failure and the differences of $K_{e}$ between them. The healthy persons were not matched with the heart failure group and are referred to as the unmatched controls (UMC). The $\mathrm{K}_{\mathrm{e}}$ was less in the patients with heart failure; and the difference $\left(\Delta \mathrm{K}_{\mathrm{u}}\right)$ was greater in men $(1024 \mathrm{mmol}, 31 \%)$ than in women (450 $\mathrm{mmol}, 20 \%)$. The difference was no greater in

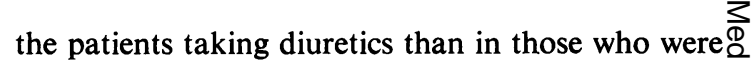
not.

However, as Table 2 shows, the patients with heart $\vec{F}$ failure were older and lighter than controls of the + ? same sex and since $K_{e}$ decreases with age and increases with weight, both these differences would $\frac{\bar{c}}{\bar{s}}$. tend to lower the average $\mathrm{K}_{\mathrm{e}}$ in the heart failure ${ }_{\bar{\sigma}}$ group. The lower $K_{e}$ in the heart failure group in $\odot$ Table 1 and in the many reports in the literature (Fig. 1) might therefore be due to a poor matching of $\vec{\circ}$ the groups for age and weight. A matched control $\rightarrow$ group could be obtained by selecting appropriate $\vec{\omega}$ patients from the total control group but this would considerably reduce the size of the control group. The approach the authors took in relation to the - . differences in age was to calculate linear regression $f$ equations of $\mathrm{K}_{\mathrm{e}}$ on age for the control group (Table o 3) and use these equations to get for each patient the.0 best estimate of the $\mathrm{K}_{\mathrm{e}}$ in a healthy person of the N same age as the patient. This best estimate was윽 the mean value of a group of healthy persons all of the same age as the patient. When this was done for ${ }_{\mathbb{D}}$

TABLE 1. Mean values of $\mathrm{Ke}_{\mathrm{e}}$ in the patients with heart failure (CHF) according to whether or not they were oedematous $( \pm \mathrm{O})$ or had diuretics $( \pm \mathrm{D})$. Also shown are the results in unmatched controls (UMC) and controls matched for age (AMC) and age and weight (AWMC) and the difference between patients and the various control groups $\left(\triangle K_{u}, \triangle K_{A}, \triangle K_{W A}\right)$

\begin{tabular}{|c|c|c|c|c|c|c|c|c|}
\hline \multicolumn{9}{|c|}{ Men } \\
\hline & $n$ & CHF & UMC & $\begin{array}{c}\text { Difference } \\
\qquad \mathbf{K}_{\mathbf{u}}\end{array}$ & AMC & $\begin{array}{c}\text { Difference } \\
\triangle \mathbf{K}_{\mathbf{A}}\end{array}$ & AWMC & $\begin{array}{c}\text { Difference } \\
\triangle K_{W A}\end{array}$ \\
\hline All & 165 & $\begin{array}{l}2240 \\
(519)\end{array}$ & $\begin{array}{l}3264 \\
(640)\end{array}$ & 1024 & $\begin{array}{l}2914 \\
(637)\end{array}$ & 674 & $\begin{array}{l}2801 \\
(633)\end{array}$ & 561 \\
\hline$+\mathrm{D}$ & 154 & $\begin{array}{l}2248 \\
(507)\end{array}$ & $\begin{array}{l}3264 \\
(640)\end{array}$ & 1016 & $\begin{array}{l}2915 \\
(637)\end{array}$ & 667 & $\begin{array}{l}2780 \\
(635)\end{array}$ & 532 \\
\hline$-\mathrm{D}$ & 14 & $\begin{array}{l}2195 \\
(599)\end{array}$ & $\begin{array}{l}3264 \\
(640)\end{array}$ & 1069 & $\begin{array}{l}2908 \\
(641)\end{array}$ & 713 & $\begin{array}{l}2923 \\
(616)\end{array}$ & 728 \\
\hline+0 & 76 & $\begin{array}{l}2218 \\
(541)\end{array}$ & $\begin{array}{l}3264 \\
(640)\end{array}$ & 1046 & $\begin{array}{l}2900 \\
(635)\end{array}$ & 682 & $\begin{array}{l}2868 \\
(641)\end{array}$ & 650 \\
\hline-0 & 92 & $\begin{array}{l}2275 \\
(488)\end{array}$ & $\begin{array}{l}3264 \\
(640)\end{array}$ & 991 & $\begin{array}{l}2934 \\
(639)\end{array}$ & 661 & $\begin{array}{l}2702 \\
(611)\end{array}$ & 429 \\
\hline \multicolumn{9}{|c|}{ Women } \\
\hline All & 168 & $\begin{array}{l}1746 \\
(454)\end{array}$ & $\begin{array}{l}2196 \\
(426)\end{array}$ & 450 & $\begin{array}{l}2116 \\
(422)\end{array}$ & 370 & $\begin{array}{l}1962 \\
(403)\end{array}$ & 216 \\
\hline$+\mathbf{D}$ & 154 & $\begin{array}{l}1758 \\
(439)\end{array}$ & $\begin{array}{l}2196 \\
(426)\end{array}$ & 438 & $\begin{array}{l}2118 \\
(421)\end{array}$ & 360 & $\begin{array}{l}1959 \\
(396)\end{array}$ & 201 \\
\hline$-\mathrm{D}$ & 14 & $\begin{array}{l}1610 \\
(594)\end{array}$ & $\begin{array}{l}2196 \\
(426)\end{array}$ & 586 & $\begin{array}{l}2098 \\
(429)\end{array}$ & 488 & $\begin{array}{l}1995 \\
(487)\end{array}$ & 385 \\
\hline+0 & 76 & $\begin{array}{l}1600 \\
(431)\end{array}$ & $\begin{array}{l}2196 \\
(426)\end{array}$ & 596 & $\begin{array}{l}2101 \\
(423)\end{array}$ & 501 & $\begin{array}{l}1972 \\
(416)\end{array}$ & 372 \\
\hline$-\mathrm{O}$ & 92 & $\begin{array}{l}1866 \\
(439)\end{array}$ & $\begin{array}{l}2196 \\
(426)\end{array}$ & 330 & $\begin{array}{l}2129 \\
(421)\end{array}$ & 263 & $\begin{array}{l}1953 \\
(394)\end{array}$ & 87 \\
\hline
\end{tabular}


TABLE 2. Age and weight (mean and s.d.) in patients with heart failure (CHF) and in unmatched controls (UMC) and age matched controls (AMC)

\begin{tabular}{|c|c|c|c|c|c|c|c|c|c|c|}
\hline & \multicolumn{5}{|c|}{ Men } & \multicolumn{5}{|c|}{ Women } \\
\hline & \multicolumn{2}{|c|}{ Age } & \multicolumn{3}{|c|}{ Weight } & \multicolumn{2}{|c|}{ Age } & \multicolumn{3}{|c|}{ Weight } \\
\hline & CHF & UMC & $\mathrm{CHF}$ & UMC & AMC & $\mathrm{CHF}$ & UMC & CHF & UMC & AMC \\
\hline All & $\begin{array}{c}54 \\
(15)\end{array}$ & $\begin{array}{c}35 \\
(15)\end{array}$ & $\begin{array}{c}66 \cdot 4 \\
(12 \cdot 1)\end{array}$ & $\begin{array}{c}71 \cdot 0 \\
(11 \cdot 8)\end{array}$ & $70 \cdot 1$ & $\begin{array}{c}52 \\
(13)\end{array}$ & $\begin{array}{c}38 \\
(17)\end{array}$ & $\begin{array}{c}56 \cdot 3 \\
(12.2)\end{array}$ & $\begin{array}{c}62 \cdot 7 \\
(14 \cdot 2)\end{array}$ & $65 \cdot 0$ \\
\hline$+D$ & $\begin{array}{c}54 \\
(15)\end{array}$ & $\begin{array}{c}35 \\
(15)\end{array}$ & $\begin{array}{c}65 \cdot 7 \\
(11 \cdot 8)\end{array}$ & $\begin{array}{c}71 \cdot 0 \\
(11.8)\end{array}$ & $70 \cdot 1$ & $\begin{array}{c}51 \\
(12)\end{array}$ & $\begin{array}{c}38 \\
(17)\end{array}$ & $\begin{array}{c}56 \cdot 0 \\
(11 \cdot 3)\end{array}$ & $\begin{array}{c}62 \cdot 7 \\
(14 \cdot 2)\end{array}$ & $65 \cdot 0$ \\
\hline$-\mathrm{D}$ & $\begin{array}{c}54 \\
(15)\end{array}$ & $\begin{array}{c}35 \\
(15)\end{array}$ & $\begin{array}{c}70 \cdot 6 \\
(12 \cdot 7)\end{array}$ & $\begin{array}{c}71 \cdot 0 \\
(11 \cdot 8)\end{array}$ & $70 \cdot 1$ & $\begin{array}{c}55 \\
(18)\end{array}$ & $\begin{array}{c}38 \\
(17)\end{array}$ & $\begin{array}{c}59 \cdot 8 \\
(19 \cdot 9)\end{array}$ & $\begin{array}{c}62 \cdot 7 \\
(14 \cdot 2)\end{array}$ & $65 \cdot 6$ \\
\hline+0 & $\begin{array}{c}54 \\
(14)\end{array}$ & $\begin{array}{c}35 \\
(15)\end{array}$ & $\begin{array}{c}69 \cdot 0 \\
(12 \cdot 5)\end{array}$ & $\begin{array}{c}71 \cdot 0 \\
(11 \cdot 8)\end{array}$ & $70 \cdot 1$ & $\begin{array}{c}54 \\
(14)\end{array}$ & $\begin{array}{c}38 \\
(17)\end{array}$ & $\begin{array}{c}58 \cdot 2 \\
(13 \cdot 5)\end{array}$ & $\begin{array}{c}62 \cdot 7 \\
(14 \cdot 2)\end{array}$ & $65 \cdot 5$ \\
\hline-0 & $\begin{array}{c}53 \\
(15)\end{array}$ & $\begin{array}{c}35 \\
(15)\end{array}$ & $\begin{array}{c}62 \cdot 5 \\
(10 \cdot 2)\end{array}$ & $\begin{array}{c}71 \cdot 0 \\
(11 \cdot 8)\end{array}$ & $70 \cdot 2$ & $\begin{array}{c}49 \\
(12)\end{array}$ & $\begin{array}{c}38 \\
(17)\end{array}$ & $\begin{array}{c}54.7 \\
(10.8)\end{array}$ & $\begin{array}{c}62 \cdot 7 \\
(14 \cdot 2)\end{array}$ & $64 \cdot 6$ \\
\hline
\end{tabular}

TABLE 3. The regression equations of $\mathrm{K}_{e}$ on age $(\mathrm{A})$, height $(\mathrm{H})$ and weight $(\mathrm{W})$ in the controls subjects (183 men, 162 women)

\begin{tabular}{|c|c|c|}
\hline & Men & Women \\
\hline $\begin{array}{l}\mathrm{K}_{\mathbf{e}}=3890 \\
\mathrm{~K}_{\mathbf{e}}=-4249 \\
\mathrm{~K}_{\mathrm{e}}=1037 \\
\mathrm{~K}_{\mathrm{e}}=-2384 \\
\mathrm{~K}_{\mathbf{e}}=\mathbf{1 7 0 6} \\
\mathrm{K}_{\mathbf{e}}=-\mathbf{7 1 8 . 4}\end{array}$ & $\begin{array}{cr}-18.17 \mathrm{~A}+42.96 \mathrm{H} & \pm 579 \\
& \pm 545 \\
-11.29 \mathrm{~A}+34.53 \mathrm{H} & \pm 523 \\
-16.84 \mathrm{~A} & +30.82 \mathrm{~W} \pm 459 \\
-14.02 \mathrm{~A}+15.08 \mathrm{H}+25.79 \mathrm{~W} \pm 450\end{array}$ & $\begin{array}{l}\mathrm{K}_{\mathrm{e}}=2427-6.03 \mathrm{~A} \\
\mathrm{~K}_{\mathrm{e}}=1283+5.72 \mathrm{H} \\
\mathrm{K}_{\mathrm{e}}=1227 \mathrm{I} \\
\mathrm{K}_{\mathrm{e}}=1940-5.75 \mathrm{~A}+2.98 \mathrm{H} \\
\mathrm{K}_{\mathrm{e}}=1433-9.10 \mathrm{~A}+15.47 \mathrm{~W} \pm 366 \\
\mathrm{~K}_{\mathrm{e}}=2525-9.96 \mathrm{~A}-7.06 \mathrm{H}+17.74 \mathrm{~W} \pm 334 \\
\pm 416 \\
\mathbf{1}+182 \mathrm{~W} \pm 331\end{array}$ \\
\hline
\end{tabular}

each patient, then the mean of these values was the best estimate of the mean value of $\mathrm{K}_{e}$ in a group of healthy persons with the same distribution of ages as the patient group.

Table 1 shows the mean values of $\mathrm{K}_{\mathrm{e}}$ calculated in this way for groups of age matched controls (AMC) and the differences between the average values of $\mathrm{K}_{\mathrm{e}}$ in the patients and in age matched controls $\left(\triangle K_{A}\right)$. The differences were much less than those from the mean values in unmatched controls (UMC). But again the difference was greater in men $(674 \mathrm{mmol})$ than women $(370 \mathrm{mmol})$, and it was if anything smaller in those patients taking diuretics than in those not taking diuretics.

There was a small difference in height between the groups. Fig. 3 shows the $K_{e}$ deficit in the patients with height measured compared with unmatched controls and controls matched for age, height and weight. The authors have included for comparison the results of their recent study in which total body potassium (TBK) was compared in patients and controls. In both cases matching for height had negligible effect on the apparent potassium deficit.

Matching for age and height does not abolish the difference in weight between patients and controls.
It was therefore necessary to take account of the differences of weight as well as age and height between the patients and the controls. The conventional approach is to use the multiple linear regression of $\mathrm{K}_{e}$ on age and weight in healthy persons in order to obtain the mean $\mathrm{K}_{\mathrm{e}}$ in age and weight matched controls (AWMC). The results are shown in Table 1. There was a further reduction in the apparent deficit of $K_{e}$, but again the deficit was greater in men than women, and there was no difference between those given diuretics and those not taking diuretics.

It seems reasonable to assume that before the patients became ill they had the same average weight as sex- and age-matched controls. On this basis it is possible to calculate the average weight loss in the patients and compare it with the apparent deficit in $\mathrm{K}_{\mathrm{e}}$. This comparison is only sensible for patients without oedema. The results are shown in Table 4.

\section{Discussion}

In a recent study the authors found that the TBK was only slightly less $(5 \%)$ in patients with heart failure than in healthy controls (Davidson et al., 1976). This contrasts with the studies reported over 

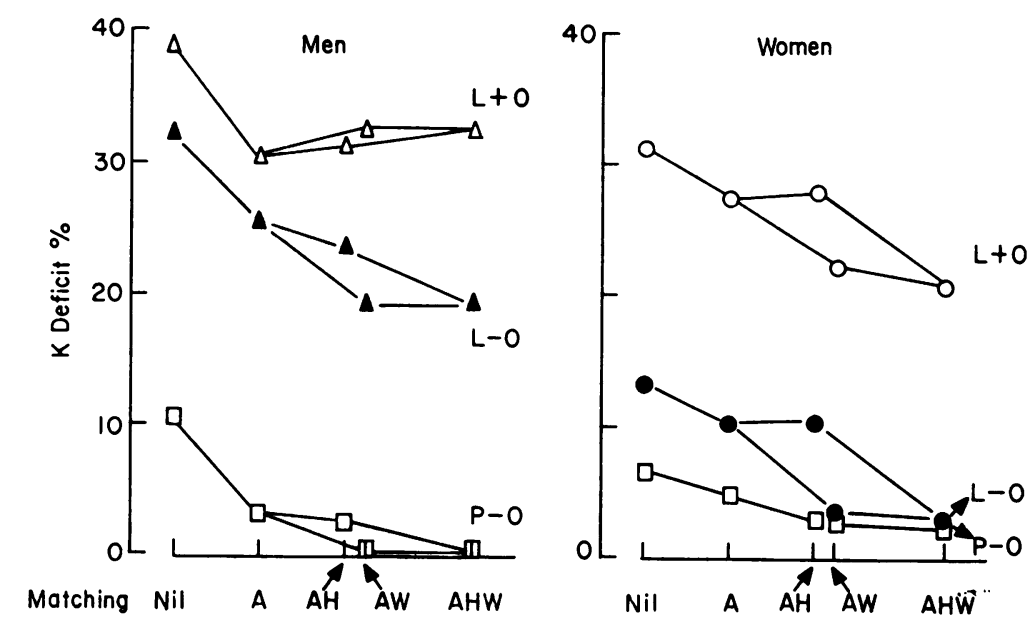

FIG. 3. The deficit of $\mathrm{K}_{\mathrm{e}}$ in patients with heart failure (who had their height recorded) calculated as a percentage of the values in reported healthy controls either unmatched or matched for age (A), age and height (AH), age and weight (AW) and age, height and weight (AHW). The results are shown for the patients reported in the literature (L) either with $(\mathrm{L}+\mathrm{O})$ or without oedema $(\mathrm{L}-\mathrm{O})$. The results are also shown for a recent study of patients without oedema $(\mathbf{P}-\mathbf{O})$ in which the patients were compared with healthy controls measured in the same department.

TABLE 4. The relation between the potassium deficit and the weight deficit in patients compared with agematched controls $\left(\triangle \mathbf{K}_{A}, \triangle \mathbf{W}_{A}\right)$ and age-height-matched controls $\left(\triangle \mathbf{K}_{A H}, \triangle \mathbf{W}_{A H}\right)$, in the literature recovery (L) and in the author's personal series (P) (Davidson et al., 1976)

\begin{tabular}{|c|c|c|c|c|c|c|c|c|}
\hline & & $n$ & $\underset{\mathrm{mmol}}{\triangle \mathbf{K}_{\mathbf{A}}}$ & $\underset{\mathbf{k g}}{\Delta \mathbf{W}_{\mathbf{A}}}$ & $\frac{\Delta \mathbf{K}_{\mathbf{A}}}{\Delta \mathbf{W}_{\mathbf{A}}}$ & $\begin{array}{l}\triangle \mathbf{K}_{\mathrm{AH}} \\
\mathrm{mmol}\end{array}$ & $\underset{\mathbf{k g}}{\Delta \mathbf{W}_{\mathrm{AH}}}$ & $\frac{\Delta \mathbf{K}_{\mathbf{A H}}}{\Delta \mathbf{W}_{\mathbf{A H}}}$ \\
\hline \multicolumn{9}{|l|}{ Men: } \\
\hline \multirow{2}{*}{$\begin{array}{l}\mathbf{L} \\
(-0)\end{array}$} & $\begin{array}{l}\text { All } \\
\text { With }\end{array}$ & 66 & -661 & $-7 \cdot 7$ & 86 & - & - & - \\
\hline & height & 39 & -746 & $-7 \cdot 3$ & 102 & -677 & -5.9 & 115 \\
\hline $\mathbf{P}$ & All & 72 & -108 & $-2 \cdot 8$ & 39 & -81 & -1.8 & 45 \\
\hline \multicolumn{9}{|l|}{ Women: } \\
\hline \multirow{2}{*}{$\begin{array}{l}\mathrm{L} \\
(-\mathbf{O})\end{array}$} & $\begin{array}{l}\text { All } \\
\text { With }\end{array}$ & 92 & -263 & -9.9 & 27 & - & 一 & - \\
\hline & height & 73 & -223 & $-8 \cdot 7$ & 26 & -224 & $-9 \cdot 1$ & 25 \\
\hline $\mathbf{P}$ & All & 61 & -118 & $-2 \cdot 0$ & 59 & -72 & $-1 \cdot 0$ & 72 \\
\hline
\end{tabular}

the last 20 years which suggested that the average deficit (using exchangeable potassium) was $20-30 \%$. The present more detailed analysis of the published studies indicates that the apparent deficit was greater in men than women, both in absolute terms and as a percentage. Indeed the loss in women was so small it would hardly cause concern. But surprisingly the present review suggests that the deficit was just as large before the introduction of potent diuretics as it has been since. Indeed in all subsequent analyses of the data the 'deficit' was no greater in patients taking diuretics than in those who were not. This is a surprising conclusion, but it is consistent with the author's own recents finding that there was no difference in TBK $^{\circ}$ between patients taking diuretics and those ${ }^{N}$ who were not (Davidson et al., 1976). In that study, the patients were taking potassium supplements aso well as diuretics, but the deficit was no greater whene the dose of potassium was negligible $(6 \mathrm{mmol} /$ day $)$, than when it was $48 \mathrm{mmol} / \mathrm{day}$.

How did the view that diuretics cause potassium 0 depletion become accepted? The authors suggest that it was because the more potent diuretics $\cong$ 
undoubtedly cause hypokalaemia, and hypokalaemia and potassium depletion are often regarded as synonymous. In addition, in the more recent studies, the patients were all taking potent diuretics and any apparent deficit they had was attributed to the diuretics.

Nevertheless, previously studied patients with heart failure (with or without diuretics) had less exchangeable potassium than healthy controls. In the literature studies and in the authors' the patients were older, lighter, and in some cases shorter than the controls. The difference in age between patients and controls is presumably due to the easy availability of young controls (students and staff) compared with older ones. These differences are all in the direction which would make body potassium less in the patients. The differences were smaller in the author's patients(Davidson et al., 1976) than in those taken from the literature, which might explain why a smaller apparent deficit was found. Can the apparent deficit be explained by these differences alone? Linear regression has been used to give the best estimate of the mean $\mathrm{K}_{\mathrm{e}}$ expected in a group of control subjects matched for age with the patients. When this is done the apparent deficit is considerably reduced in the literature group and in the author's 1976 study.

The patients were also shorter than the controls, but the difference is small, and matching the controls for height as well as age has little effect on the apparent deficit. Other authors have corrected for height differences by using the regression of $\mathrm{K}_{e}$ on height and age (Flear et al., 1966; White et al., 1969) or by calculating the ratio of $\mathrm{K}_{\mathrm{e}}$ to height (Blainey et al., 1954). But a low $\mathrm{K}_{\mathrm{e}}$ for height could be due either to a cellular depletion of potassium or to a loss of potassium-containing tissue (particularly muscle). It is therefore clearly necessary to take account of body weight in the interpretation of the body potassium.

In the early studies, differences in weight were taken into account by calculating $\mathrm{K}_{\mathrm{e}} / \mathrm{kg}$ body weight (Blainey et al., 1954; Moore et al., 1954; Wilson et al., 1954; Aikawa and Fitz, 1956; Birkenfeld et al., 1958). But the linear relation of $K_{e}$ on weight does not pass through the origin so that the ratio varies with weight and cannot be used to correct for differences of weight. The same argument probably applies to the ratios of potassium to dry body weight (Cox $e t$ al., 1971) and lean body mass (Croxson et al., 1972).

An alternative approach is to use linear regression to match the patients and the controls in terms of weight as well as age and height. The results of this approach suggest that there is a true deficit of potassium in patients with heart failure although this is much less than the apparent deficit before correction.
However, there are several points to be considered in interpreting the differences obtained by matching the patients and controls for weight. Weight in healthy persons is made up of a mixture of several tissues of differing potassium contents, and the relationship between $K_{e}$ and weight in healthy persons is determined by differences in the mixture between heavy and light people. An apparent deficit in $\mathrm{K}_{e}$ in a person who has lost weight through disease could be due to differences in the mixture rather than or as well as a decrease in the potassium content of the tissues. Thus an apparent deficit in relation to weight could arise in the individual if he gained a potassium-poor material such as oedema fluid, or lost a potassium-rich material. In this context a potassium-rich material would be one with a potassium content $(\mathrm{mmol} / \mathrm{kg})$ which is greater than the slope of the linear regression of TBK on weight in the healthy persons $(30 \mathrm{mmol} / \mathrm{kg}$ in men, 15 $\mathrm{mmol} / \mathrm{kg}$ in women). Muscle is an example of a potassium-rich tissue as its potassium content is about $90 \mathrm{mmol} / \mathrm{kg}$ wet weight.

Flear and his colleagues (1966) concluded that there was a cell depletion of potassium in patients with heart failure because the $\mathrm{K}_{\mathrm{e}}$ was low in relation to oedema free weight; but his finding also could be explained by a loss of a potassium-rich tissue. White et al. (1969) and Olesen and Valentin (1973) concluded that the low $\mathrm{K}_{\mathrm{e}}$ they detected was due to muscle wasting because there was a relation between the potassium deficit and the loss of weight. However, what White and his colleagues (1969) demonstrated was a statistically significant correlation between $\mathrm{K}_{e}$ (as a percentage of $\mathrm{K}_{e}$ predicted from height) and weight (as a percentage of standard weight for age, sex and height). Such a relationship would be expected even in a group of healthy persons, and in any case the authors did not show that the relationship was a reasonable one in terms of the potassium content of tissues. Olesen and Valentin (1973) based their conclusions on similar data and the same arguments can be made about their study.

In the present review, in the patients without oedema, the $\mathrm{K}_{\mathbf{e}}$ loss $/ \mathrm{kg}$ weight-loss was greater than the slope of the regression of $\mathrm{K}_{\mathrm{e}}$ on weight in healthy persons. The difference which was greater in men than women, could be due to the loss of a potassiumrich tissue (such as muscle) or a true cellular depletion of potassium, or both. However, the ratio between potassium loss and weight loss was no greater than the potassium content of muscle. The apparent $\mathrm{K}$ deficit could therefore be explained by muscle wasting without a true cell depletion. It is clearly impossible to attempt any detailed interpretation of the body potassium in patients with obvious but unknown amounts of oedema. The observed $\mathrm{K}_{\mathrm{e}}$ in oedematous men was the same as in 
non-oedematous men although they were $6.5 \mathrm{~kg}$ heavier and they could therefore have had the same amount of muscle as the patients without oedema.

It is therefore suggested that none of the previous and often quoted studies provides evidence of a true cellular depletion of potassium in patients with heart failure. The apparent deficits of potassium which have been repeatedly observed could be due to muscle wasting. Differences in the extent of muscle wasting could explain why the apparent deficits were greater in men than women and greater in previous studies than this recent one. This interpretation would also explain why the deficit was the same in the patients who were taking diuretics as in those who were not, and why it was not related to the type of diuretic or to the presence of hypokalaemia.

A general conclusion is that it is difficult if not impossible to detect potassium depletion by a single measurement of TBK or $\mathrm{K}_{\mathrm{e}}$ when there are changes in body composition. This conclusion applies to measurements on groups as well as individuals.

The role of the measurement of $\mathrm{K}_{e}$ or TBK in the detection of true potassium depletion is probably as the most sensitive index of potassium retention when patients are treated with potassium. Recent studies suggest that patients with heart failure do not retain potassium when they are given it and are therefore not potassium-depleted (Davidson, Burkinshaw and Morgan, 1978). This review of the literature suggests that there is no evidence that severe cellular potassium depletion was ever common in patients with heart failure.

\section{References}

AIKAWA, J.K. \& FiTz, R.H. (1956) Exchangeable potassium content of the body in congestive failure changes during treatment. Circulation, 14, 1093.

Aikawa, J.K., Harrell, G.T. \& Eisenberg, B. (1952) The exchangeable potassium content of normal women. Journal of Clinical Investigation, 31, 367.

Arons, W.L., VANDERlinde, R.J. \& Solomon, A.K. (1954) The simultaneous measurement of exchangeable body sodium and potassium utilizing ion exchange chromatography. Journal of Clinical Investigation, 33, 1001.

Birkenfield, L.W., Leibman, J., O'Meara, M.P. \& EdelMAN, I.S. (1958) Total exchangeable sodium, total exchangeable potassium, and total body water in edematous patients with cirrhosis of the liver and congestive heart failure. Journal of Clinical Investigation, 37, 687.

Blainey, J.D., Cooke, W.T., Quinton, A. \& Scott, K.W. (1954) The measurement of total exchangeable potassium in man, with particular reference to patients with steatorrhoea. Clinical Science, 13, 165.

Carroll, H.J., Gotterer, R. \& Altshuler, B. (1965) Exchangeable sodium, body potassium and body water in previously edematous cardiac patients. Circulation, 32, 185.

Corsa, L., Olney, J.M., Steenburg, R.W., Ball, M.R. \& MOORE, F.D. (1950) The measurement of exchangeable potassium in man by isotope dilution. Journal of Clinical Investigation, 29, 1280.
Cox, J.R., Horrocks, P., Speight, C.J., Pearson, R.E. \& HOBSON, N. (1971) Potassium and sodium distribution in cardiac failure. Clinical Science, 41, 55.

Crooks, J., BluhM, M.M. \& Mudowney, F.P. (1959) The interrelation between total exchangeable sodium, potas sium and chloride, and lean body mass in man. Clinicag Science, 18, 175.

Croxson, M.S., Neutze, J.M. \& JohN, M.B. (1972) Ex $\overline{\bar{\sigma}}$ changeable potassium in heart disease: Long-term effect of potassium supplements and amiloride. American HearD Journal, 84, No. 1, 53.

Davidson, C., Burkinshaw, L., Maclachlan, M.S.F. $\&^{\text {W }}$ Morgan, D.B. (1976) Effect of long-term diuretic treat $\vec{\sigma}$ ment on body-potassium in heart disease. Lancet, ii, 1044:-

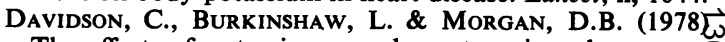
The effects of potassium supplements, spironolactone of amiloride on the potassium status of patients with hearg failure. Postgraduate Medical Journal, 54, (in press).

Davidson, C. \& Gillebrand, I.M. (1973) Use of amiloride. as a potassium conserving agent in severe cardiac disease $\triangle$ British Heart Journal, 35, 456.

DEAN, N. \& SMITH, H.W. (1952) The distribution of sodium and potassium in man. Journal of Clinical Investigation, $31 ; \mathrm{N}$

Deuxchaisnes, C.N., Collett, R.A., Busset, R. \& Mach? R.S. (1961) Exchangeable potassium in wasting amyotrophy, heart-disease, and cirrhosis of the liver. Lancet, $i_{\pi}$ 681 .

Flear, C.T.G., Quinton, A., Carpenter, R.G., Domenet J.G. \& SIVYER, A. (1966) Exchangeable body potassium and sodium in patients in congestive heart failure. Clinicak chimica acta, 13, 1.

IKkos, D., LJUNGGREN, H., LufT, R. \& SJOGREN, B. (1989) Content and distribution of potassium and chloride adults. Metabolism: Clinical and Experimental, 4, 231 .

LJUNGGREN, H., IKkos, D. \& LuFT, R. (1957) Studies of bợ composition. Acta endocrinologica, 25, 187.

MacGillivray, I., Buchanan, T.J. \& Billewicz, W.Z (1960) Values of total exchangeable sodium and potassium in normal females based on weight, height and age $\frac{\circ}{\mathbb{Q}}$ Clinical Science, 19, 17.

MoORe, F.D., Edelman, I.S., Olney, J.M., James, A.H. $\overrightarrow{\vec{\sigma}}$ Brooks, L. \& WILSON, G.M. (1954) Body sodium and potassium III. Interrelated trends in alimentary, renal and cardiovascular disease; lack of correlation between body stores and plasma concentration. Metabolism, 3, 334.

Olesen, K.H. (1964) Body composition in heart disease.o. Total exchangeable potassium, total exchangeable sodium total exchangeable chloride and derived values for bodyo composition in cardiac disease with and without oedema. Acta medica scandinavica, 175, No. 3. 301.

OLESEN, K.H. (1968) Body composition in heart disease. Total exchangeable electrolytes in normonatraemic hypo chloraemia. Danish Medical Bulletin, 15, 111.

Olesen, K.H. \& VAlENTIN, N. (1973) Total exchangeable potassium, sodium and chloride in patients with severe valvular heart disease during preparation for cardiac surgery. Scandinavian Journal of Thoracic and Cardiovas $-\bar{N}$ cular Surgery, 7, 37.

SAGILD, U. (1956) Total exchangeable potassium in normain subjects with special reference to changes with age. NN Scandinavian Journal of Clinical and Laboratory Investiga-w tion, 8, 44.

SinGH, B.N., HuRley, P.J., NorTh, J.D.K. (1969) The use ole amiloride in potassium depletion before cardiac surgery. $\frac{\digamma}{\Phi}$ American Heart Journal, 78, 22.

Skrabal, F., ARNOT, R.N. \& Joplin, G.F. (1973) Equations? for the prediction of normal values for exchangeable $T$ sodium, exchangeable potassium, extracellular fluid ${ }_{\vec{P}}$ volume and total body water. British Medical Journal, 2, 37. 
Talso, P.J., Miller, C.E., Carballo, A.J. \& Vasquex, I. (1960) Exchangeable potassium as a parameter of body composition. Metabolism: Clinical and Experimental, 9, 456.

White, R.J., Chamberlain, D.A., Hamer, J., McAlister, J.
\& Hawkins, L.A. (1969) Potassium depletion in severe heart disease. British Medical Journal, 2, 606.

Wilson, G.M., Edelman, I.S., Brooks, L., Myrden, J.A., Harken, D.E. \& Moore, F.D. (1954) Metabolic changes associated with mitral valvuloplasty. Circulation, 9, 199. 